(C) Н.Е. Мазалова

\title{
СТАНОВЛЕНИЕ И ДЕЯТЕЛЬНОСТЬ ПЕТЕРБУРГСКОЙ ЦЕЛИТЕЛЬНИЦЫ И ПРОРИЦАТЕЛЬНИЦЫ ЮРОДИВОЙ МАТРОНЫ БОСОНОЖКИ
}

В статье предпринимется попытка создать портрет знаменитой петербургской юродивой Матроны. Уделяется внимание ее социальному статусу, сочииокультурному облику, особенностям мировоззрения, морально-этическим принциипам, различным деяниям. Исследование проблем вопроса женского юродства, странничества, а также биографические исследования выдающиихся женщин, направленные на изучение субъективного опыта, повседневного и ритуального поведения индивидуума в конкретную историческую эпоху, относятся к числу актуальных в исторической науке. Образ Матронь Босоножки представляется значимым объектом исследования в пространстве гендерных отношений в исторической ретроспективе и в настоящее время, поскольку до наших дней не утрачен интерес кее личности. Автором проведено исследование изменения сочиильного статуса Матроны. На примере петербургской блаженной исследованы проблемы милосердия и жертвенности. Отмечены особенности петербургского юродства. Особое внимание уделено вопросам выбора подвига юродства, который у Матроны был обусловлен несколькими обстоятельствами, среди которых несчастливая личной жизнь, смерть двух мужей, пребывание в статусе солдатки, и в большей мере - сестры милосердия, а также пережитые ужасы войны. Проанализирована деятельность Матроны как иелительнищы и прорицательницы. Актуальность работе придает рассмотрение сохранения представлений о целительских и провидческих способностях блаженной Матроны Босоножке в наши дни во время эпидемии коронавируса.

Ключевые слова: юродивые, женское юродство, петербургские юродивые, странничество, святость, жертвенность, ичелительство

Ссылка при цитировании: Мазалова Н.Е. Становление и деятельность петербургской целительницы и прорицательницы юродивой Матроны Босоножки // Вестник антропологии, 2022. № 1. С. 193-207.

Мазалова Наталия Евгеньевна - д.и.н., старший научный сотрудник Отдела этнографии восточных славян и народов Европейской России, Музей антропологии и этнографии РАН (190034 Санкт-Петербург, Университетская наб., д. 3). Эл. почта: mazalova.nataliya@mail.ru orcid.org/0000-0001-7586-4506 


\section{THE HOLY FOOL, HEALER AND PROPHETESS FROM ST. PETERSBURG MATRONA THE BAREFOOT: HER LIFE AND ACTIVITY}

The article attempts to portray the famous holy fool from St. Petersburg to describe her social status, socio-cultural appearance, worldview, moral and ethical principles, and deeds. The studies of the female holy foolishness, wandering, and biographical studies of outstanding women aimed at studying their subjective experience, everyday and ritual behavior in a specific historical era, are relevant in historical science. The character of Matrona the Barefoot is important in the light of gender relations in historical retrospect and now, since interest in her personality has not been lost to this day. The author conducted a study of the change in Matrona's social status. The St. Petersburg holy fool serves as an example for investigating the issues of charity and sacrifice. Special attention is paid to choosing the feat of foolishness, which Matrona did due to several circumstances: an unhappy personal life, the death of two husbands, her status as a female soldier and a nurse, the horrors of war she experienced. The article analyzes Matrona's activity as a healer and prophetess. The author discusses the popularity of ideas about the powers of the blessed Matrona the Barefoot in our days during the coronavirus epidemic.

Keywords: holy fools, female fools, St. Petersburg fools, pilgrimage, holiness, sacrifice, healing

For Citation: Mazalova, N.E. 2022. The Holy Fool, Healer and Prophetess from St. Petersburg Matrona the Barefoot: her Life and Activity. Herald of Anthropology (Vestnik Antropologii) 1: C. 193-207.

Author Info: Mazalova, Natalia E. - Doctor of History, Peter the Great Museum of Anthropology and Ethnography (Kunstkamera) of the Russian Academy of Sciences (St. Petersburg, Russia). E-mail: mazalova.nataliya@mail.ru, https:// orcid.org/0000-0001-7586-4506

Матрона Босоножка (Мыльникова)- местночтимая блаженная и юродивая, которая пользовалась широкой известностью в Петербурге на рубеже XIX - XX вв. Она прославилась чудесными исцелениями, пророчествами и поразительной человеческой добротой. Это была удивительная женщина, отказавшаяся от мирских радостей и целиком посвятившая себя служению людям и Богу.

В статье предпринимается попытка проследить становление и деятельность петербургской целительницы, уделить внимание ее социальному статусу, социокультурному облику, особенностям мировоззрения, морально-этическим принципам, деяниям. Исследование проблем вопроса женского юродства, а также биографические исследования выдающихся женщин, направленные на изучение субъективного опыта, повседневного и ритуального поведения индивидуума в конкретную историческую эпоху, относятся к актуальных в исторической науке. Образ Матроны Босоножки представляется значимым объектом исследования в исторической ретроспек- 
тиве и в настоящее время, поскольку до наших дней не утрачен интерес к личности Матроны, рассказы о ней бытуют среди петербуржцев, могилу ее посещает множество людей, и это обуславливает необходимость изучения ее личности.

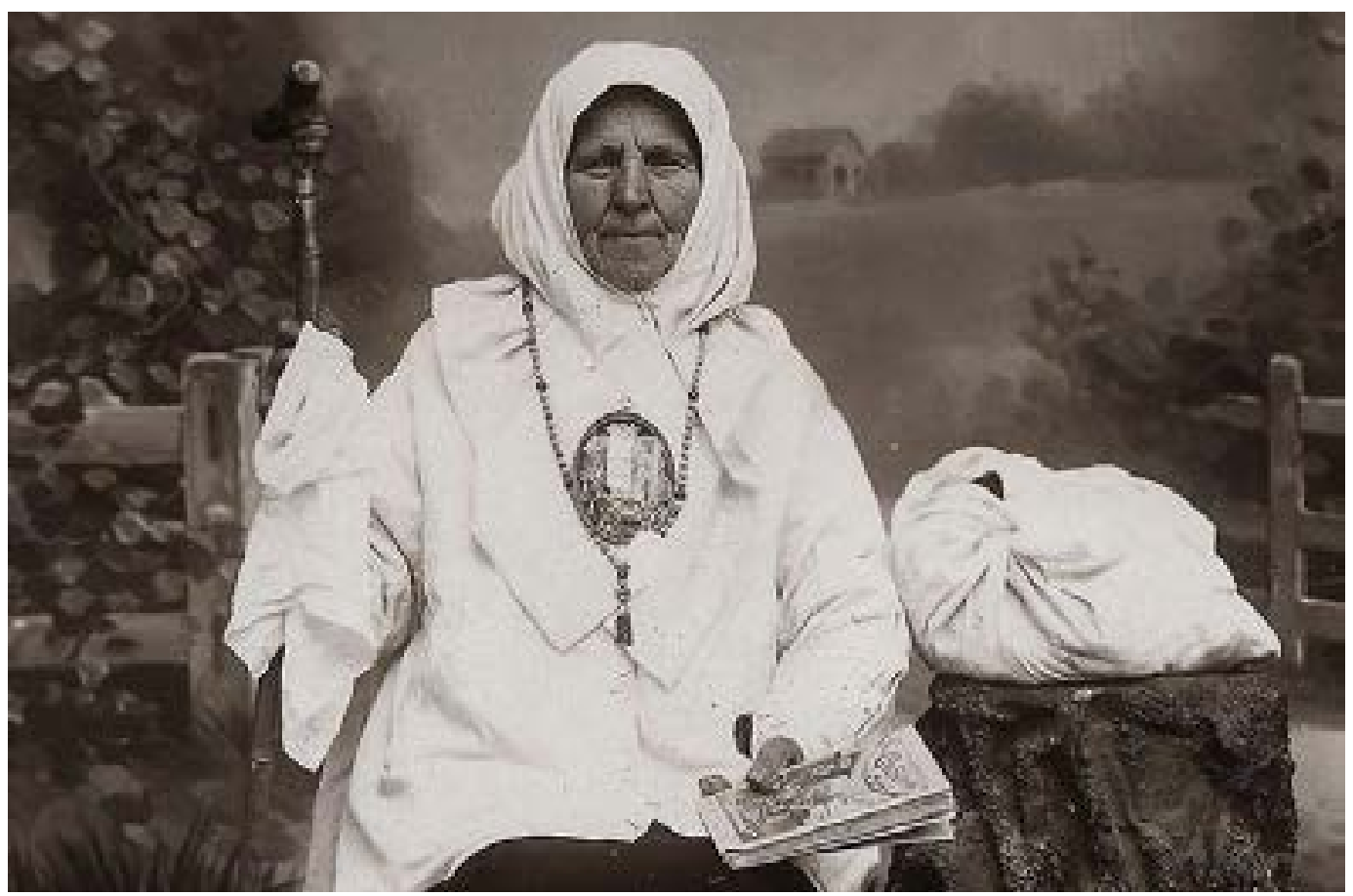

Рис. 1. «Матрона Босоножка с посохом странницыл». Начало ХХ в. Мастерская К Булльл. Fig. 1. "Matrona the Barefoot with a wanderer's staff".

Beginning of the XX century. K. Bulla's Studio.

Жизненный путь Матроны кратко представлен в книге ее биографа А.Ф. Плотникова (Жизнеописание 1912). Кроме того, в недавно опубликованной книге «Жизнеописание петербургской старицы Матроны Петровны Мыльниковой (Матроны Босоножки)» появились новые сведения: богословы проделали огромную работу по уточнению многих моментов ее биографии (Жизнеописание 2019). Вместе с тем, некоторые эпизоды ее жизни до настоящего времени окутаны тайной. С личностью Матроны связано множество мифов и ее личность следовало бы определить как мифологизированную. Юродивая в восприятии окружающих предстает как реально живший человек, как стереотипизированный социальный образ и как мифологический образ, причем три эти образа накладываются друг на друга (Мазалова 2011: 215).

По уточненным богословами данным, родилась Матрона весной 1833 г. в д. Ванино Оделеевской волости Нерехтского уезда Костромской области (Жизнеописание 2019: 15). О ее детстве и отрочестве ничего не известно. Вероятно, ее крестили в церкви с. Одолеево на родине блаженного Симона Юрьевецкого Чудотворца. Несомненно, с самого раннего детства Матрона слышала рассказы о жизни и подвигах этого юродивого, широко бытовавшие в ее местности. К сожалению, не удалось обнаружить сведений о призвании Матроны к юродству, которое нередко проявляются в детстве или отрочестве; например, у Матроны Московской в раннем детстве открылся дар предвидения и целительства. 
В 1850 г. Матрону выдали замуж за Ивана Федорова в с. Антоново. В 1852 г. у нее родился сын Андрей, в 1853 г. - сын Иван. В 1855 г. ее мужа забрали в рекруты (Жизнеописание 2019: 21). В ревизских сказках 1857 г. нет сведений о Матроне (Жизнеописание 2019: 21). Возможно, она числилась как рекрутская жена. Отдача мужа в солдаты значительно изменяла социальный статус его жены - крестьянки, которая переходила в разряд солдаток. Солдатка должна была адаптироваться к новым условиям, поменять привычный образ жизни: она или следовала за мужем к месту службы или занималась отходничеством, так обычно поступали жены рекрутов. Главными занятиями солдаток в городах являлась работа в качестве прислуги, на фабрике, мелкая торговля, стирка белья и т.п. (Щербинин 2006).

Если женщина оставалась в семье мужа, она, как правило, оказывалась на грани нищеты, поскольку ее муж был потерян как работник для его семьи, кроме того, она исключалась из членов общины и не получала ни от нее, ни от помещика никакой помощи, следовательно, лишалась какой бы то ни было поддержки. Вместе с тем, Матрона, являясь до этого крепостной, освободилась от крепостной зависимости, что свидетельствует об изменении ее социального статуса. Таким образом, впервые Матрона оказалась исключенной из привычного крестьянского социума, став солдаткой.

Об этих годах жизни Матроны ничего не известно. Хотя очевидно, что ее жизнь жизнь рекрутской жены была тяжелой. Об этом свидетельствуют русский фольклор, прежде всего - причети. Так, в «Плачах по женатом рекруте» И.А. Федосовой описано общественное и семейное положение солдатки, у нее двойственное положение она не жена и не вдова, ее дети - сироты:

«И поостанусь я, печальная головушка,

И не вдовой да буду слыть - женой не мужнеей,

И я бессчастною солдаткой горегорькою.

И сироты будут солдатски мои детушки....» (Федосова 1981: 134).

Вместе с тем, бедственное положение солдаток нередко побуждало их к выработке активной жизненной позиции и к противодействию обстоятельствам, чтобы спасти себя и детей. Таким образом, можно предположить, что пребывание в статусе солдатки стало первым серьезным жизненным испытанием Матроны.

Через несколько лет после возвращения из армии в 1870 г. муж Иван Федорович Румянцев умер от пьянства, и Матрона овдовела. Вдова, имеющая детей, должна была оставаться в семье мужа или, получив паспорт, отправиться на заработки. Вероятно, Матрона переехала в Кострому, где через некоторое время вышла замуж за мещанина Егора Мыльникова (Жизнеописание 2019: 25). Он был мелким торговцем, имел бакалейную лавку и собственный дом (Жизнеописание 1911: 5-6). О жизни Матроны в Костроме нет сведений. Кострома в XIX в., как и в наши дни, была центром духовной православной жизни, где действовали ученики Сергия Радонежского, например, Аврамий Чухломской и Галицкий, который основал здесь 4 монастыря (в разное время в Костромской земле было открыто более 60 монастырей). Очевидно, что Матрона приобщается к духовной, религиозной жизни этого города.

Второе замужество позволило Матроне вновь поменять (повысить) свой сословный и социальный статус, из крестьянской вдовы перейти в сословие мещан. И впоследствии весь дальнейший жизненный пусть Матроны не был связан с крестьянским бытом. По крайней мере, в период жизни в Костроме Матрона не бедствовала. Однако известно, по словам Матроны, записанным ее биографом, и этот брак Ма- 
троны не был счастливым: он «был тяжелым испытанием. Она в брачной жизни перенесла много огорчений» (Жизнеописание 1911: 5-6).

До 40 с лишним лет Матрона вела образ жизни, соответствовавший нормам традиционного русского социума: она исполняла обязанности жены, матери. Поэтому неожиданным кажется ее поступок: в 1877 г. Матрона вслед за мужем отправилась сестрой милосердия на Русско-турецкую войну. В архивных документах в списках костромских сестер милосердия Матрона Мыльникова не значится, вероятно, она поехала на войну вольнонаемной или волонтером (Жизнеописание 2019: 45).

До середины XIX в. в России война была исключительно мужским занятием. Впервые сестры милосердия из Крестовоздвиженской общины участвовали в Крымской войне. В действующей армии на передовой, в госпиталях они проходили специализированную подготовку. Руководство процессом формирования нового социального и профессионального института сестер милосердия осуществлял знаменитый врач Н.И. Пирогов. Тогда и сформировалось представление о сестрах милосердия, которые выносят раненых с поля боя, помогают хирургам проводить операции, ухаживают за ранеными (Власов 2003; Максимова 2006).

Институт сестер милосердия, возникший в России в середине XIX в. под западно-европейским влиянием, испытавший воздействие зарождавшихся капиталистических отношений, вместе с тем, в значительной мере развивался под влиянием православия, его важнейшей идеи и высшей христианской добродетели - милосердия (Лебедев 2020). Милосердие - готовность помочь кому-либо из сострадания, человеколюбия. Именно в православной традиции «милосердие» понимается как сочетание христианского доброго дела и внутреннего душевного сопереживания. Милосердие это «некая сила, энергия, порождаемая человеком, способна воздействовать на других людей, на события, процессы, проявляется в социуме» (Шалгина 2020: 38).

Сестры милосердия воспринимали свой труд как христианское служение страждущим (Правдиковская 2012: 11). Всех их объединяло главное - стремление помочь страждущим, облегчить их страдания. Труд сестер милосердия был очень тяжелым: они, зачастую, без сна и отдыха должны были наблюдать за ранеными, выполнять все предписания врачей, стирать белье и др. Их подстерегало множество опасностей: они могли погибнуть на передовой, заразиться тифом и другими болезнями. В свободное время сестры милосердия выполняли просьбы больных - писали письма, читали книги. В их обязанности также входило нравственное попечение о душевном состоянии больных: они читали для них молитвы, приглашали священников и др.

В народной песне «Милосердная сестра» описана сестра милосердия, которая пробирается с театра военных действий с санитарным отрядом. У нее убит муж на войне, «сердце кровью облито», «сама едва живая, вся измучена, больна», но она находит в себе силы успокаивать раненых:

«Скоро мы на пункт приедем,

Накормлю вас, напою,

Перевязку все поправлю

И всем письма напишу». 
Все эти обязанности исполняла и Матрона Мыльникова. Ее судьба напоминает судьбу героини песни: муж Матроны тоже был убит на войне, по другим сведениям - умер от болезни во время военных действий.

Большая часть сестер милосердия были достаточно молодыми, и уже одно то, что Матрона отправилась на войну в зрелом возрасте - в 44 года, характеризует ее как человека высокой гражданской позиции, милосердного и готового жертвовать собой ради других, подобно множеству сестер милосердия. Однако в русской истории есть соответствие этому факту: предтечей института сестер милосердия было петербургское общество «сердобольных вдов», объединявшего женщин разных возрастов (Галустян и др. 2018).

Наряду с другими сестрами милосердия, Матрона Мыльникова, несомненно, сыграла важную роль в повышении значимости женщин в русском социуме, «в процессе роста социальной активности женщин в России в XIX - начале XX вв., в процессе общей демократизации общества, в просвещении населения и в нравственном влиянии на жизнь общества» (Правдиковская 2012: 8).

Институт сестер милосердия являлся одним из немногих всесословных учреждений в России. Известно, что во время Первой мировой войны обязанности сестер милосердия исполняли императрица и ее дочери. Самая известная сестра милосердия - фрейлина Императорского двора баронесса Юлия Петровна Вревская продала всё своё имущество и снарядила на вырученные деньги санитарный поезд Красного креста. В Болгарии на передовых позициях она перевязывала раненых, ассистировала хирургам при операциях, выхаживала больных. Баронесса заболела сыпным тифом и скончалась.

В посвященном ей стихотворении Я. Полонского «Под Красным крестом» есть строки, где Ю. Вревская сравнивается с белым ангелом:

И странно, в тот миг, как она замелькала,

Как дух, над которым два белых крыла

Взвились, - белый ангел (Полонский 1986: 209).

Благодарные раненые часто называли сестер милосердия «святыми» и «ангелами». Именно этими же характеристиками наделяет современная православная поэтесса Лилия Евсеева Матрону Босоножку: она для нее «белый ангел». В образе Матроны Босоножки главными стали черты милосердной христианки, которые удивительно точно передала Л. Евсеева, назвав ее «сестрой во Христе милосердия» в песне «Белый ангел», посвященной Матроне Босоножке:

«И русскому люду - богатым и бедным,

Сестрой во Христе милосердья была».

Этот образ соединяет два понятия - «сестра во Христе»- христианка, и «сестра милосердия» - врачевательница и утешительница. Причем милосердие Матроны активная, деятельная сила, важный ценностный ориентир, который во многом определил ее поведение и отношение к людям.

Матрона в статусе сестры милосердия в очередной раз изменила свой социальный статус и приобрела профессиональный, поскольку деятельность сестер милосердия была выделена в новую профессиональную сферу - медицину. Став сестрой милосердия, Матрона освоила некоторые специальные навыки и получила право на оплату своего труда. Но и в использовании заработанных ею денег проявлялась жертвенность Матроны. Как отмечает ее биограф, будучи сестрой милосердия, «в 
должности которой получала 25 руб. жалованья, но жалованье она тут же раздавала бедным солдатам» (Жизнеописание 1911: 8). В этом наличествует деятельное отражение христианской любви и служения обездоленному ближнему.

Таким образом, в этот период жизни Матрона проявилась в образе русской сестры милосердия - активного и равноправного члена общества, патриота своей родины и милосердной женщины. Матрона теперь не только мать, жена, хранительница домашнего очага, но и гражданка, от деяний которой зависели судьбы многих раненых. По мере изменения социального статуса Матрона приобретала «гражданские свободы», которые потом позволили ей принять осознанный и свободный выбор - целиком посвятить себя религиозному подвижничеству. После войны и смерти мужа на войне Матрона в 1878 г. продала имущество, раздала деньги нищим и отправилась странствовать. В это время Матроне было 45 лет. С этого времени начался путь религиозного подвижничества с его жертвенностью и милосердием, на который Матрона вступила во время русско-турецкой войны и который она уже не оставила никогда.

Изучение религиозных воззрений Матроны и ее деяний позволяет уточнить некоторые аспекты гендерных проблем явлений женского странничества и юродства. В русской традиции странники - люди, «главное содержание жизни которых составляет хождение по святым местам (монастырям, местным сельским святыням) на богомолье» (Щепанская 2005: 639). Статус странника был неопределенным, он переставал быть членом крестьянской общины или - как это было с Матроной - мещанкой и т.п. Странничество не было нормой для члена традиционного общества: «Среди странников было значительной число людей, чье поведение отклонялось от нормальной (по традиционным представлениям) модели мужского или женского поведения» (Щепанская 2005: 639). Среди них были внебрачные дети, старые девы, бобыли, инвалиды, а также - вдовы, к которым принадлежала Матрона. Следует отметить, что странствование - преимущественно мужское занятие, женщин-странниц в русской традиции было значительно меньше, чем мужчин.

Жизнь странников была нелегкой: они питались, чем подадут люди, или тем, что заработают, ночевали либо у людей, либо в лесу, в поле и т.д. Зачастую странников привечали за рассказы о дальних странствиях по святым местам, и чем дальше они бывали и чем более значимы были посещаемые ими святыни, тем выше был статус странника, тем охотнее их оставляли на ночлег и кормили. Матрона посетила наиболее значимые для верующих святыни. Записанные от Матроны рассказы о посещении ею святых мест напоминают по стилю и патетике традиционные нарративы странников: «Бог сподобил меня побывать четыре раза в Иерусалиме, поклониться Гробу господню и другим святыням. Была я в Соловках, и на Валааме, и у Троицы Сергия, и в Сарове, и десятки раз бывала в более близких монастырях. Везде какая в обителях благодать Божия и сколько в них утешения» (Баженов 1916: 333-334).

Обычно люди отправлялись странствовать по обету - обещанию, данному в случае болезни - своей или близких, однако для Матроны причины были иными, для нее странничество было осознанным выбором, желанием посвятить себя Богу: она «отправилась странствовать, наложив на себя трудный подвиг юродствующей Христа ради, и первый путь ее - босиком - был к Соловецким чудотворцам» (Жизнеописание 1911: 6).

Вероятно, выбор подвига юродства Матроной был обусловлен несколькими обстоятельствами: несчастливая личная жизнь, смерть двух мужей, пребывание в ста- 
тусе солдатки, и в большей мере - сестры милосердия, а также пережитые ужасы войны. Служение в качестве сестры милосердия, вероятно, можно рассматривать как один из главных стимулов выбора пути юродства. Недаром до конца жизни Матрона носила белый платок, наподобие головного убора сестер милосердия. Матрона сознательно оставила мирские блага и отправилась странствовать, а затем вернулась в мир нравственно очищенной и стала юродивой, по народным представлениям, юродство - это вид святости.

На примере Матроны прослеживаются некоторые характерные признаки женского юродства. Матрона в начале странствования дала обет - не носить обувь. Нагота полная или частичная (босоножество) является одним из признаков юродства. Представления о наготе в народной культуре и в христианстве различны, однако они взаимосвязаны и помогают охарактеризовать образ юродивых. В народной культуре признак нагой - одетый соотносится с бинарной оппозицией «природа - культура». Обнажение - способ возврата в природное состояние. Босоногость - частичная нагота, ей придается особое культурной значение: позитивное влияние на плодородие. Босоногость - это отличительный признак женщин-юродивых, например, босыми ходили св. Пелагея Дивеевская, св. Параскева Дивеевская, тогда как для мужчин более характерным было полное обнажение: например, святой Василий Московский, ходил нагим круглый год в течение десятков лет, за что его прозвали прозывались «нагоходцем». В христианстве в контексте библейских текстов босоногость трактуется иначе: она служит символом смирения и почитания Бога, как выражение благоговения в присутствии Бога (Райкен 2005).

В дальнейшем петербургская полиция не раз задерживала Матрону Босоножку за нарушение общественного порядка - постоянное хождение по городу без обуви. Матрона была вынуждена подать прошение в Святейший синод, где объясняла свое хождение босиком данным Богу обетом: «Полиция говорит, что я смущаю народ, но если я его смущаю, то разве только доказательством, что Господь посылает еще милосердие рабам своим, допуская на морозе не мерзнуть раздетым ногам у тех, кто дал ему обет в этом послушании. Может ли такое доказательство вселить в души людей иное, кроме поддержки православных заветов» (РГИА. Ф.796. Д.2770. Л.1).

Как правило, за редким исключением, юродивые - и мужчины, и женщины были девственниками. Сохранение девственности - ритуальной чистоты было одним из способов их контакта с Богом, а также испытанием в их подвиге. Следует отметить редкую для юродивых черту: у Матроны были дети (например, Ксения Петербургская была замужем, но у нее детей не было). К моменту отправления в странствование Матрона была дважды вдова, отметим, что второй брак считался дозволенным по нормам традиционного общества. Вдова, по народным представлениям, с одной стороны, считалась социально неполноценной. По христианским предписаниям, нашедшим отражение в Библии, брак - это образ семейной полноты; вдовство - образ утраты и пустоты. С другой стороны, вдова, по народным представлениям, обладала ритуальной чистотой, поскольку не вступала в сексуальные отношения. Например, с другими ритуально чистыми женщинами - девушками, старыми девами, старухами - вдовы выполняли охранные функции: проводили обряд опахивания во время эпидемий и эпизоотий.

Следовательно, статус вдовы - ритуально чистой женщины - позволил Матроне отправиться в странствование по святым местам и готовиться к новому статусу юродивой как переходу из одного состояния - мирянки - в другое. 
В народной традиции обряды перехода включают элемент изоляции («временную смерть»). И в христианстве странничество рассматривалось как временная смерть: «Уходя из прежней жизни, от семьи, родного места, страны, духовный странник как бы умирал для родных и вступал на путь, ведомый одному Богу. Паломничество в древние времена было, без сомнения, подвигом веры» (Серафим (Парамонов).

Испытав «временную смерть», Матрона возродилась в новом статусе - юродивой, блаженной, однако это статус проявился несколько позже. После трех лет странничества она в 1881 г. перебралась в Петербург на постоянное место жительство. Повод переселения - здесь жил ее сын, и она хотела быть поближе к нему. Однако, несомненно, были более глубокие причины переезда Матроны в столицу. Петербург - имперский город с особой мифологий, особой атмосферой являлся местом, в котором в XVIII-XX вв. подвизались в подвиге юродства много блаженных, причем, за редким исключением, это были женщины. Кроме Ксении Петербургской, широко известны были Анна Ивановна Лукашева, Марфа, Ирина, Анна Ивановна Комисарова, Ольга Ивановна, Мария Лелянова, Мария Маковкина, Параскева Ивановна Ковригина и др. Знаменательно, что первоначально Матрона поселилась на Петербургской стороне, где начинали строить Петербург и где начинала юродствовать самая известная петербургская блаженная Ксения Петербургская.

Появилась Матрона в Петербурге в начале 1880-х гг., а первые сведения о ее целительской и провидческой деятельности датированы концом 1890-х гг. Вероятно, получение дара - длительный процесс, который сопровождался молитвами и трудами. Возможно, Матрона и ранее проявляла свой дар, однако широкую известность она приобрела только в указанное время.

Матрона жила на Васильевском о-ве, молилась в Андреевском соборе. Как пишет священник Андреевского собора А. Нумеров о занятиях Матроны, известной среди прихожан под именем «Матрены Босой» или «Матрены блаженной», к ней обращались с просьбами представители разных сословий и возрастов помолиться об исцелении, о получении места службы, о выходе из затруднительного положения (ЦГИА. Ф. 19. ОП. 89. Д. 70. Л. 9 об.).

Матрона была известна в разных районах Петербурга. Так, в кронштадской городской газете «Котлин» за 1896 г. появилась заметка: «Разные странники и юродивые нет-нет, да и появятся в нашем городе. Так, в воскресенье 23-го июня на пристани... внимание привлечено было многочисленной толпой народа, окружившею какую-то плохо одетую, босоногую женщину по имени Матрена. Каждому из подходящих она давала какой-либо совет или указывала на одну из слабостей его характера. Женщины подводили детей и Матрена их благословляла, снабжая медными образками, крестиками и книжками» (Котлин 1896: 3).

Матрона в белом легком одеянии, босиком - зимой и летом с посохом причудливой формы бродила по улицам Петербурга. Она не брала ни от кого денег, если ей пытались их вручить, то жертвовала их на масло и свечи для церкви. Вокруг Матроны собирались толпы народа, иногда более 300 человек, которые просили исцеления, предсказаний будущего. Матрона принимала больных и просящих ее совета также у себя на квартире, иногда до 100 человек в день.

Матрона в результате испытаний приобрела от Бога дар предвидения и предсказания. В соответствии с народными представлениями, она была посредницей между Богом и людьми, по ее словам, она могла «только помолиться с просящими об ис- 
полнении желаний их» (ЦГИА. Ф. 19. Оп. 89. Д. 70. Л. 11). По народному мнению и собственному убеждению Матроны, ее молитвы об исцелении или помощи кому-либо, обращенные к Богу, приносили положительные результаты. Так, протоирей $\Phi$. Ставровский сообщает: «Мыльникова ... не отрицает в себе дара исцеления и прозорливости. Имеет при себе икону Божьей Матери, про которую икону говорит, что она чудотворная» (ЦГИА. Ф. 19. Оп. 89. Д. 70. Л. 9 об.).

Матрона была также наделена даром предвидения будущего, а это дар - удел немногих избранных, в том числе, юродивых. Следует отметить, что некоторые люди, в соответствии с народными представлениями, считали, что Матрона - гадалка и колдунья, приходили к ней погадать о будущем, однако Матрона заявляла им, что она не является ни тем, ни другим, а может только молиться вместе с ними и просить Бога о помощи.

Она предсказывала судьбы не только отдельных людей, в том числе - выдающихся, например, Столыпина, - но и страны: в 1910 г. она заявила: «...У меня семь лампадочек погасло...В Россиюшке что-то будет нехорошо» (Жизнеописание 1911: 15).

Важный вопрос исследования проблемы юродства - взаимоотношения блаженных с властью. Мужчины-юродивые, в отличие от женщин, как правило, находились в оппозиции к ней, хулят ее. У Матроны взаимоотношения с властью складывались следующим образом. С исполнительной и карательной властью отношения у нее были сложные. Как уже говорилось, полиция постоянно задерживала Матрону за нарушение общественного порядка - скопления народа, хождение босиком и пр. В начале 1897 г. благодаря огромной популярности среди петербуржцев, особенно низших слоев, Матрона попала в поле зрения полиции. Санкт-Петербургской сыскная полиция послала прошение в Духовную консисторию, в котором говорилось о необходимости провести расследование деятельности Матроны. В Консистории завели «Дело о костромской мещанке Матроне Петровне Мыльниковой, называемой в народе «блаженная Матренушка». Священникам прихода, в котором проживала Матрона, было поручено «испытать религиозные убеждения» Мыльниковой, выяснить, является ли она истинной православной и не распространяет ли она сектантские учения. В конце XIX - начале XX вв. в России широкое распространение получили различные секты -богоискатели, хлысты и др.

Один из священников, участвовавших в расследовании, докладывал, что Матрона не является сектанткой, но признает в себе дар исцеления и прозорливости: «Обращающимся к ней больным дает воды и деревянного масла. Собраний в ее квартире никогда не бывает, ни общих молитв, ни церковных песнопений. Посетителей она впускает к себе по одному и редко двоих...По всему видно, что Мыльникова не сектантка» (ЦГИА. Ф. 19. Оп. 89. Д. 70. Л. 9 об.).

Несмотря на положительные свидетельства священников, по делу Матроны был вынесен следующий вердикт: «Костромская мещанка Матрона Петровна Мыльникова не обнаруживает никаких признаков принадлежности к сектантству, но обнаруживает самомнение о присущем ей даре исцелений и своеволии в устроении приема посетителей и собирании денег на масло и свечи и распространении печатных изданий...» (ЦГИА. Ф. 19. Оп. 89. Д. 70. Л. 23). Ввиду перечисленного было принято решение о прекращении Матроной приема посетителей и собирании денег на свечи и масло. Таким образом, хотя с Матроны было снято подозрение в принадлежности к какой-либо секте, но ей было запрещено заниматься целительством и собирать деньги на церковные нужды. 
Ее отношение к верховной власти было особым: Матрона была очень предана императорской семье, она постоянно молилась за ее членов. Известно, что Матрона в религиозные практики подносила подарки царствующей семье: иконы, просфоры, лампадное масло и др. Как правило, подарки эти принимались, хотя, как известно, все подношения царской семье тщательно рассматривались канцелярий по делам императрицы и без ее указаний их не брали. Матроны три года молилась о рождении наследника. Когда родился цесаревич Алексей, она замыслила строительство Алексеевского монастырского подворья и направила прошение императору и императрице с подарком - золоченным иконостасом с иконой св. Преподобного Серафима Саровского. К сожалению, прошение не было удовлетворено.

Есть сведения, что по приказанию государя Матрона, имеющая статус прозорливой старицы, была представлена царской семье, после чего она получила свободный доступ ко дворцу и нередко общалась с императором и императрицей (Жизнеописание 2019: 161). Объяснение этому кроется в особом отношении Николая и еще в большей степени - Александры Федоровны к странникам, старцам, которые, по их мнению, сохраняли истинную православную веру. Императрица считала, что понять русский народ можно, только поняв православие и ее истинных носителей. В тяжелые периоды испытаний царская власть в России обращалась за помощью к вере.

По некоторым сведениям, императрица была глубоко опечалена смертью Матроны и прислала на ее похороны крест из белых живых роз (Жизнеописание 2019: 161).

Но все-таки основная деятельность Матроны-подвижницы протекала в иной среде - среди простых людей. Последние 16 лет ее жизни связаны с Невской заставой, территорией Стеклянного завода. Это был промышленный район Петербурга, в котором в конце XIX - XX вв. располагалось более 30 заводов. Он был как провинциальный русский город: деревянные дома, сточные канавы, антисанитария, поскольку здесь располагалась городская свалка. Вспышки холеры и сыпного тифа нередко начинались здесь. Рабочие жили бедно, впроголодь, их традиционная еда - квас с добавлением нескольких картофелин и лука. Нередко рабочих увольняли, в их среде был распространен алкоголизм.

Именно сюда переселилась Матрона, к часовне Скорбященской Божьей Матери, расположенной у Стеклянного завода. Формальная причина переселения - жить поближе к внучке и ее семье. Но именно в этом неблагополучном районе среди бедных, неблагополучных людей в полной мере раскрылся ее талант - служить людям, облегчать их нелегкую жизнь.

Несмотря на запрет властей, Матрона продолжала собирать пожертвования, лечить больных и предсказывать будущее. Об этом, в частности, свидетельствует справка сыскной полиции от 13 марта 1899 г. о Матроне: «Мыльникова, 70 лет, проживающая в настоящее время в доме № 6-8-10 по Ново-Александровской улице, где занимает одну небольшую комнату № 29. Мыльникова ходит постоянно босою, носит белую одежду и часто появляется для сбора подаяний у церкви «Всех скорбящих», принимает только медную монету. Квартиру ее посещают почитатели, чтущие Мыльникову за юродивую» (ГАТО. Ф. 632. Оп. 1. Д. 20. Л. 92). Петербургский бытописатель А.А. Бахтиаров, автор известной книги «Брюхо Петербурга», описывая свою встречу с Матроной - «местной босоногой святой», которой на освящении Скорбященской часовни 20 декабря 1909 присутствующие почтительно уступали дорогу, сравнивал ее с чтимыми во всей России юродивыми: «..Сквозь толпу про- 
биралась вперед какая-то женщина, вся в белом и босая...Она с таким усердием молилась перед алтарем, делая земные поклоны, что нисколько не шокировала религиозные чувства богомольцев - в своем странном одеянии....Я заинтересовался босоножкой, т.к. слышал, что это - местная юродивая и в самые жестокие морозы ходит босой. И стал наблюдать за ней, как за человеком не от мира сего, как отголоском древней благочестивой старины, которая изобиловала «юродствующими во Христе». Подобно Василию Блаженному, предсказавшему пожар Москвы, Прокопию Устюжскому, предсказавшему каменный дождь в Великом Устюге, и Ксении Блаженной, предсказавшей в свое время смерть императрицы, Матрона Босоножка тоже обладала даром предсказывания» (Бахтиаров 1909: 6).

Большую часть собранных денег Матрона жертвовала бедным, потерявшим работу, больным, остальные деньги отправляла на строительство церкви «Всех Скорбящих радость (с грошиками)». Эта церковь построена в честь иконы Божьей Матери «Всех скорбящих радость», чудесным образом уцелевшей во время пожара в Тихвинской часовне в 1885 г. на территории Стеклянного завода. Кроме того, известно, что Матрона занималась сбором пожертвований для деревенских приходов - в Тверской губернии, на ее родине в Костромской губернии и др.

Саму Матрону, как и всех юродивых, отличало нестяжательство и отрицание материальных благ, жила она очень скромно в полуразвалившемся домике, спала на убогой постели, покрытой ветошью, питалась моченым хлебом или похлебкой (На могилке 1911: 2). Когда муж внучки лишился работы, и она обратилась за помощью к бабушке, Матрона дала ей несколько фунтов хлеба и 40 копеек денег и сказала: «Слава Тебе, Господи! Мы все здоровы и сыты. А вот храм Господен беден и великую нужду терпит наша церковь, много еще сирых и нищих, а я для Бога только живу и только для Бога и тягость на себя великую приняла, не могу я нового греха на душу взять, я исполняю волю молящих и должна отдавать деньги по назначению. А это, что вам даю, - мое подаяние» (На могилке 1911: 2).

Матрона предсказала и собственную смерть, в начале марта 1911 г. она сказала: «Вот пойдет на Неве лед; вместе с водой и льдом и я уйду от вас». Она действительно скончалась в ледоход 30 марта 1911 г. На похороны Матроны собралось огромное количество людей - ее почитателей. Полиция дежурила у ее квартиры, поскольку проститься с ней шли толпы людей. Затруднено было даже движение поездов проходившей недалеко от дома Невской пригородной железной дороги.

По просьбам населения Невской заставы похоронена Матрона была в ограде Скорбященской церкви. Через несколько лет над ее могилой была возведена маленькая часовня, а сама могила стала местом поклонения. К ней приходили помолиться и попросить помощи в бедах и болезнях множество верующих.

В 1933 г. через год после закрытия Скорбященская церковь была разобрана на кирпичи. Часовня функционировала до 1938 г. Могила Матроны была затеряна. Однако чудеса продолжались. Одно из самых известных: посадка на Неву в 1963 г. самолета ТУ-134, у которого отказали двигатели, как раз неподалеку от могилы блаженной. Причем никто из пассажиров и экипажа не пострадал. Верующие считают, что самолет спасла Матрона.

С начала 90-х гг. ХХ в. часовня действует как храм в честь иконы «Всех Скорбящих Радость (с грошиками)» и до недавнего времени являлась подворьем Зеленецкого Свято-Троицкого мужского монастыря. 3 мая 1995 г. была обнаружена могила 
Матроны, которая в скором времени вновь стала местом поклонения. В наши дни нескончаемым потоком идут к могиле Матроны Босоножки ее почитатели, просят избавить их от болезней и бед.

Матрона является персонажем современной мифологии прихрамовой петербургской среды. Священниками Скорбященской церкви собрано более 500 свидетельств чудес - нарративов об избавлении от болезней, помощи в поиске работы и др. после молитв, обращенных к Матроне Босоножке. Эти нарративы представляют собой сообщение об одном (редко - двух) событии - чуде. Структура таких нарративов следующая: беда, недостача (болезнь, безработица, отсутствие жилья и др.) - молитвенное обращение к Матроне, которая выполняет функции «чудесного помощника», - ликвидация беды, недостачи (выздоровление, приглашение на работу, получение жилья и др.) (В.Я. Пропn). Функция таких рассказов - информативная и в большей мере - доказательная: они являются доказательством того, что Матрона и в наши дни творит чудеса. Такие рассказы содержат удивительную для рассказчика информацию и обусловлены ситуативно: они обычно произносятся во время встреч верующих, в них рассказывается о чудесных случаях, участниками которых были сами рассказчики, либо они являлись их свидетелями.

Огромное количество рассказов о чудесах, приписываемых Матроне, зафиксировано в письменной форме, это - уникальный случай для фольклора прихрамовой среды отдельной церкви. Запись рассказов о чудесах в письменной форме определена тем, что идет процесс канонизации Матроны. Церковь должна в соответствии со сложившейся традицией определить, является ли Матрона Мыльникова святой, причем учитываются не только подвижничество и чудеса, приписываемые какой-либо личности, но также и ее народная оценка.

Во время пандемии к числу молитв, обращенных к Матроне, добавились просьбы от избавления от общей беды - коронавируса. К Матроне обращаются с просьбами излечить заболевших коронавирусом близких и предохранить от заболевания себя, семью и всех людей.

Во время карантина в Скорбященской церкви, расположенной в сохранившейся часовне, не закрывавшейся ни на один день, были предприняты все меры безопасности: использовалась одноразовая посуда, например, причащали одноразовыми ложечками. Иконы и киот постоянно протираются, храм проветривается. Были единичные случаи заболевания коронавирусом - как среди священников Скорбященской церкви, так и прихожан, однако массовой эпидемии не произошло. Прихожане считают, что это благодаря заступничеству и покровительству Матроны Босоножки.

На месте взорванной Скорбященской церкви построена новая, которая вероятно, откроется уже в ближайшее время. Идет процесс канонизации Матроны. Церковь должна в соответствии со сложившейся традицией определить, является ли Матрона Мыльникова святой. Вместе с тем, церковь учитывает не только подвижничество и чудеса, приписываемые какой-либо личности, но также и ее народную оценку. Церковь не запрещает молитвы к каким-либо праведникам, не канонизированным ею, а в народном сознании Матрона является святой, она воплощает идеал и высшую духовную ценность: «святой - это тот человек, в ком пребывает особый вид духовно благодатного возрастания, называемого святостью» (Топоров 2005: 4). Ее святость - это высший нравственный идеал поведения, а ее неустанная помощь людям - это жертвенность особого рода. 


\section{Источники и материалы}

ГАТО - Государственный архив Тверской области (ГАТО). Ф. 632. Оп. 1. Д. 20. Л. 92.

РГИА - Российский государственный исторический архив (РГИА). Ф. 796. Д. 2770. Л. 1

ЦГИА - Центральный государственный исторический архив Санкт-Петербурга (ЦГИА). Ф.19. Оп.89. Д. 70. Л. 9 об.; Ф. 19. Оп. 89. Д. 70. Л. 2.

Баженов - Баженов И.В. Матренушка-босоножка // Костромские епархиальные ведомости. 1916. Отдел. Неоф. № 24. С.333-344.

Бахтиаров 1909 - Бахтиаров А.А. Торжество освящения часовни «Всех Скорбящих Радости»// Петербургская газета. 1909. 21 декабря. С.6

Котлин 1896 - «Котлин» (газета). 1896. № 119. С. 3.

Жизнеописание 1912 - Жизнеописание в Бозе почившей рабы Божией Старицы Матроны Петровны Мыльниковой (Матренушки-Босоножки)/ Сост. А.Ф. Плотников. СПб.: Издательство Е.В. Киселева, 1912. 32 с.

Жизнеописание 2019 - Жизнеописание петербургской старицы Матроны Петровны Мыльниковой (Матроны Босоножки)/ Сост. Л.А. Юревичиене. Под редакцией иер. Полевой Б.Ю., иер. Титов Г.М. СПб: ООО «Издательство «Левша» Санкт-Петербург. 2019. 224 с.

На могилке 1911 - На могилке и в квартире Матренушки-босоножки // Ведомости С.-Петербургского градоначальства. 1911. № 81.16 апреля. С.2.

Полонский 1986 - Полонский Я. П. Стихотворения. Поэмы / Сост. и вступ. ст. В.Г. Фридлянд; М.: Правда, 1986. 480 с.

Федосова 1981 - Федосова И. А. Избранное / Сост., вступ. ст. и коммент. К.В. Чистова; Подгот. текста Б.Е. Чистовой, К.В. Чистова. Петрозаводск: Карелия, 1981. 303 с.

Научная литература

Власов П.В. Обитель милосердия. М.: Моск. рабочий, 1991. 303 с.

Война и милосердие. М.: Свято-Димитр. училище сестер милосердия, 2003. 320 с.

Галустян В.Г., Урбанский Д.А., Фатеев А.И. Становление сестринского дела в России и формирование общин сестер милосердия // Вестник совета молодых учёных и специалистов Челябинской области, 2018. № 3 (22) Т. 3. С. 7-9.

Лебедев св., иеромонах Лука (Пронских). Основные этапы формирования благотворительного института общин сестер милосердия на Западе и в России // Христианское чтение. Научный журнал Санкт-Петербургской Духовной Академии Русской Православной Церкви, 2020. № 2. C. 20-28.

Мазалова Н.Е. Этнографические аспекты изучения личности «знающего». XIX - начало XXI в. Санкт-Петербург: Петербургское востоковедение, 2011. 301 с.

Максимова Л.Б. Княгиня Наталья Борисовна Шаховская и основанная ею община «Утоли моя печали» // Вестник церковной истории. М., 2006. № 4. С. 237-240.

Панченко А.М. Русская история и культура. Работы разных лет. СПб.: Юна, 1999. 515 с.

Правдиковская Е.Н. Общины сестер милосердия в культуре России. Дис. к. культур.н. М.: Моск. гос. ун-т культуры и искусств, 2012. 196 с.

Серафим (Парамонов) иером. О паломничестве и странничестве // Азбука веры. URL: http: / azbyka.ru)

Словарь библейских образов /Райкен Л., Уилхолт Д., Лонгман Т. Санкт-Петербург: Библия для всех, 2005 (ГУП Тип. Наука).

Топоров В.Н. Святость и святые в русской духовной культуре. Том 1. М.: Гнозис, 2005. 245 с. Шалгина Е.А. Образная составляющая концепта «милосердие» // Вестник ПНИПУ. Проблемы языкознания и педагогики № 3. 2020. С. 34-48.

Щепанская Т.Б. Странник // Мужики и бабы. Мужское и женское в традиционной русской культуре. СПб.: «Искусство СПб», 2005. С. 639-642. 
Щербинин П.П. Солдатские жены в XVIII - начале XX в.: опыт реконструкции социального статуса, правового положения, социокультурного облика, поведения и настроений // The-Journal-of-power-institutions-in-post-soviet-societies. 2006. № 4-5.

\section{References}

Galustyan, V.G., Urbanskij, D.A., Fateev, A.I. 2018. Stanovlenie sestrinskogo dela v Rossii i formirovanie obshhin sester miloserdiya [The formation of nursing in Russia and the formation of communities of sisters of mercy]. In Vestnik soveta molody 'x uchyony 'x $i$ specialistov Chelyabinskoj oblasti. 3 (22): 7-9.

Lebedev, sv., ieromonax Luka (Pronskix). 2020. Osnovny`e e`tapy` formirovaniya blagotvoritel`nogo instituta obshhin sester miloserdiya na Zapade i v Rossii [The main stages of the formation of the charitable institute of the Sisters of Mercy communities in the West and in Russia]. Hristianskoe chtenie. Nauchny j zhurnal Saint Petersburgskoj Duhovnoj Akademii Russkoj Pravoslavnoj Cerkvi 2: 20-28

Mazalova, N.E. 2011. E`nograficheskie aspekty`izucheniya lichnosti "znayushhego", XIX-nachalo XXI v. [Ethnographic aspects of the study of the personality of the "knower". XIX-early XXI century.] Saint Petersburg: Peterburgskoe vostokovedenie.

Maksimova, L.B. 2006. Knyaginya Natal ya Borisovna Shaxovskaya i osnovannaya eyu obshhina «Utoli moya pechali» [Princess Natalia Borisovna Shakhovskaya and the community founded by her "Assuage my sorrows"]. Vestnik cerkovnoj istorii 4: 237-240.

Panchenko, A.M. 1999. Russkaya istoriya i kul tura. Raboty` razny`x let [Russian history and culture. Papers of different years]. Saint Petersburg: Yuna.

Pravdikovskaya, E.N. 2012. Obshhiny 'sester miloserdiya v kul ture Rossii [Communities of Sisters of Mercy in the culture of Rus]. Moscow.

Rajken L., Uilxolt D., Longman T. (ed.). 2005. Slovar` biblejskix obrazov [Dictionary of Biblical Imagery Downers Grove: Inter Varsity Press, 1998]. Saint Petersburg: Bibllija dlja vseh (English: Dictionary of Biblical Imagery Downers Grove: Inter Varsity Press, 1998).

Serafim (Paramonov) ierom. O palomnichestve i strannichestve [About pilgrimage and pilgrimage]. In Azbuka very' [The Abc of Faith]. URL: http: /azbyka.ru.

Shalgina, E.A. 2020. Obraznaya sostavlyayushhaya koncepta «miloserdie» [The figurative component of the concept of "mercy"]. Vestnik PNIPU. Problemy yazy koznaniya i pedagogiki. 3: 34-48.

Shepanskaya, T.B. 2005. Strannik [The Wanderer]. In Muzhiki i baby. Muzhskoe i zhenskoe v tradicionnoj russkoj kul ture [Men and women. Male and female in traditional Russian culture], 639-642. Saint Petersburg: «Iskusstvo Saint Petersburg».

Sherbinin, P.P. 2006. Soldatskie zheny` v XVIII - nachale XX v.: opy`t rekonstrukcii social nogo statusa, pravovogo polozheniya, sociokul turnogo oblika, povedeniya i nastroenij [Soldiers' wives in the XVIII - early XX century: experience of reconstruction of social status, legal status, socio-cultural appearance, behavior and moods]. The Journal of power institutions in post soviet societies. 4/5 (on line). https://doi.org/10.4000/pipss.493

Toporov, V.N. 2005. Svyatost` i svyaty 'e v russkoj duxovnoj kul 'ture [Holiness and Saints in Russian Spiritual Culture]. Vol 1. Moscow: Gnozis.

Vlasov, P.V. 1991. Obitel miloserdiya [The Abode of Mercy]. Moscow: Moskovskij Rabochij.

Vojna i miloserdie [War and mercy]. 2003. Moscow: Svyato-Dimitr. uchilishhe sester miloserdiya. 